See discussions, stats, and author profiles for this publication at: https://www.researchgate.net/publication/324864767

\title{
Managing the Technology for Selectively Collecting Solid Waste in the Western Amazon Sub Region
}

Article in Journal of Solid Waste Technology and Management · February 2018

DOI: 10.5276/JSWTM.2018.43

CITATIONS

0

5 authors, including:

Elávio de São Pedro Filho
Universidade Federal de Rondônia

91 PUBLICATIONS 20 CITATIONS

SEE PROFILE

Fabricio Almeida

Universidade Federal de Rondônia

93 PUBLICATIONS 703 CITATIONS

SEE PROFILE

Some of the authors of this publication are also working on these related projects:

Project $\quad$ SCIENT: A European University-Business Alliance aiming to foster young SCIEntists' ENTrepreneurial spirit View project

Project A case study on reducing call drops through Spectrum auctions: An Empirical Cross National Investigation View project
READS

55

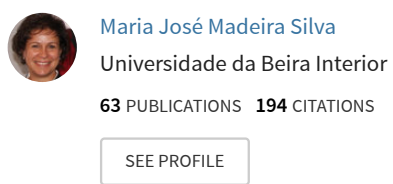




\title{
MANAGING THE TECHNOLOGY FOR SELECTIVELY COLLECTING SOLID WASTE IN THE WESTERN AMAZON SUB REGION
}

\author{
Norma Maria Coelho Vieira*, Master's Degree in Environmental Sciences from the University of Taubaté (UNITAU), Brazil. Voluntary member of \\ the Research Group on Innovation Management and Technology (GEITEC) at the Federal University of Rondônia (UNIR), Brazil \\ coelho.norma@gmail.com
}

Marcelo José Peres Gomes da Silva, Specialist in Computer Networks and Data Communications at the State University of Londrina (UEL), Brazil

Flávio de São Pedro Filho, Doctor in Business Administration from USP. Professor of Management of UNIR. Coordinator GEITEC - Research Group Management of Innovation and Technology of the Federal University of Rondônia (UNIR), Brazil. Post-doctoral Candidate in Economics and Management, focusing on Strategy Management for Innovation and Sustainability, in the University of Beira Interior, Covilha, Portugal

Maria José Aguilar Madeira, Ph.D. in Management and Economics at the University of Beira Interior (UBI), Covilha, Portugal

Fabricio Moraes de Almeida, Doctor in Physics, Professor and Researcher for the Doctoral Course in Regional Development and Environment at the Federal University of Rondônia (UNIR), Brazil, Deputy Coordinator of GEITEC - Research Group on Management for Innovation and Technology, UNIR

\begin{abstract}
This study's main objective is to study the complexity of technological management of the collection of solid waste, through the prism of reverse logistics; and to propose certain specific objectives: (1) to describe the form of concentration of solid waste in the group studied; (2) to analyze the impact of the volume of solid waste; and (3) to propose intervention measures for solid waste management. It asks what technology management model should guide the selective collection of solid waste in the Amazon. Based on the theory of convergence, it studies the strategy of competitive advantage in understanding the organizational system in the environment in which it operates; on this theory, Nobre (2011) addresses knowledge as a source that transmits competitive edge in order to contribute to a company's organizational system. The research is qualitative and descriptive; it applies the Case Study method, and related procedures. As a study, it confirms that the investigated collector cooperatives are vulnerable, which influences the conclusions of this study. It finds that the collectors employed by these organizations are the significant environmental agents in the process of reusing and recycling materials and thus play a key role in reverse logistics because they can return the waste to the production chain adding value and promoting shared management,. The results also point to the absence of a system to promote environmental education, despite the potential viability of the materials and regardless of the possible economic and social improvements to the Amazonians and their families. The system proposed here involves the selective collection of solid waste by intelligent machines, applying reverse logistics. This study could benefit business people, the government and other stakeholders in public policy and sustainability in fragile environments such as the Brazilian Amazon.
\end{abstract}

Keywords: Amazon. Management. Innovation. Solid Waste. Technology

\section{INTRODUCTION}

Concern about global warming is creating a clear need for solutions that will modify actions that were once designed to avoid new environmental impacts and efficiently manage natural resources. The issue of water quality is of major importance in this regard, following failure in the treatment of waste. It is inconceivable that the Amazon region, location of

*Correspondence author 
the largest river basin in the world, should suffer from a lack of technology for managing solid waste. The present research takes a global interest approach, considering the advanced development resulting from the installation of hydroelectric power plants, the benefits of the inter-oceanic highway and the completion of the Pacific railroad. The consequent volume of debris exceeded any rational amount and this situation has been aggravated by a lack of appropriate policies and failure to disabuse residents and business owners of their environmental illusions.

Suitable persuasion and centers of excellence indicate one way forward, proposing a solution via research, together with techniques and interventionist measures for promoting ecological equity while seeking to minimize the impact. One such solution is the application of reverse logistics, since solid residue is essential raw material for other products required by a consumer society.

The overall objective of the present research is to investigate the complex technological management of waste collection in the Western Amazon sub region, focusing on reverse logistics. This requires (1) a description of the concentration of solid waste in the area in question and the naming of specific objectives for its deployment; (2) an analysis of its impact in the Western Amazon, focused on the state of Rondonia; and (3) suggestions for interventions to manage it. The goal is a technology management model that would cope efficiently with the selective collection of solid waste in this area.

\section{THEORETICAL REVIEW AND CONCEPT}

This study is based on contingency theory, in which Nobre (2011) translates knowledge as the source of competitive edge which contributes to a company's organizational system. According to him, this theory addresses the impact of technology and the environment on issues to do with solid waste; it sets up a model of organizational perception that formulates business strategies developed in an organizational network of solidarity, i.e. in a company with cognitive vision.

The study involves concepts of reverse logistics as set out in the National Plan of the Brazilian Government for solid waste (2010); this conceptualizes reverse logistics as a strategic instrument whereby solid waste can be collected and returned to the business market for reuse, as is environmentally proper.

Human actions have caused environmental degradation which contravenes the laws designed for environmental protection. Uncontrolled consumerism has been a key factor in the worldwide increase of solid waste. The Amazon region has suffered more acutely than elsewhere from this problem with the intensive practice of logging and forestry burning. Tachizawa (2011) states that the planet's natural systems have limited ways of containing today's rampant consumerism, and records the damage and the importance of sustainable development, but more research is needed on the effects of the surplus thus generated.

Theoretical and conceptual applications in Brazil (2010) indicate that waste represents the morphology in which it is generated, whether solid or semi-solid, organic or nonorganic, urban or non-urban. It is produced by everyday activities, individual and collective. Thus, if the Ministry of the Environment in the Brazilian Federal Government indicated that reverse logistics was one of the enforcement tools for sharing responsibility in the life cycle of products it would be interpreted as encouraging the operational convergence of the logistics to counter the collapse in the study of waste treatment.

A survey in Brazil (2010) shows that solid waste can be classified as physical, chemical or biological, according to its composition; or in accordance with its origin (as industrial, hospital, urban, agricultural); also, as hazardous or nonhazardous, according to the degree of danger it presents to public health and the environment; and by being recyclable or non-recyclable. In relation to the critical analysis that the present study employs, it should be recalled that the factors which define the characteristics of solid waste are related to social, economic, cultural, geographical and climatic questions.

\section{Solid waste in the Amazon region}

A Brazilian law of 2010 conceptualizes solid waste as rejected material resulting from human action, characterized as solid or semi-solid, organic or non-organic, urban or nonurban, hazardous or non-hazardous.

The lack of public policies in the creation of landfills and the selective collection in the Amazon region, such as in the State of Rondônia, has resulted in concentrations of solid waste in open dumps. This reveals the fragility of the country's social framework regarding solid waste management. Across the country children's activities in garbage dumps have been the rule rather than the exception. Many countries, however, have already transcended this level and transformed environmental problems in their sustainable development. Dias (2014) supports the overall view that change, while urgently needed, is feasible, since only human actions caused the environmental impact in the first place.

While the threats are constant, they can be turned into strengths if they lead to the improved management and organization of technology and prompt other agents (providers) in the supply chain to become involved.

\section{SWOT Analysis}

A SWOT analysis is a technique for improving system management in strategic planning procedures; it collaborates systematically to analyze internal and external variables (D'Ambros, 2012). Having done so, it can be used to find the appropriate words for developing business strategies and facilitating a beneficial relationship between business and resources. As D'Ambros (2012) remarks, an interesting aspect of this methodology is that it is easy to involve the actors in the strategic marketing process.

Although the Amazon region works well as a reactor indicating the balance of global environmental stability, Sweden will lead the next reform in the uses of energy by practi- 
cal actions that will produce efficient global business models for the management of solid waste. As Demajorovic (2014) states, companies in developing countries rarely make a habit of reusing solid waste, or have any experience of disposing of it appropriately. What has forced waste collectors to organize themselves into cooperatives or associations, thus strengthening the network of economic solidarity by cooperating through shared management and without individualism?

\section{Public Policy}

The Paraná State Environmental website in Brazil suggests that public policies, including various programs or actions developed by civil servants with the participation of organized civil society, have had an outstanding significance. They ensure, inter alia. that civil rights as determined by legal standards reaching all segments of society have effectively secured socio-cultural, economic, and environmental benefits, A practical example of the implementation of public policy by government can be seen in the actions of the secretariat to safeguard the effectiveness of incorporation as practiced by this governmental body. They show its institutional commitments as they arise from the regulations and legal procedures, resulting in the protection and conservation of the natural environment in the area where this research was conducted.

Denhardt (2015) considers the systemic convergence in the formatting of public policies implemented by governments and reports that environmental preservation dominates the intentions behind its waste management policy. Strategic actions in the national policy for solid waste have been instrumental in its progress, resulting in methods and procedures for maximizing the economic and social benefits of the proper treatment of waste which Denhardt outlines. The consequence has been consolidated production chains committed to the technical procedure of focusing recommendations on reverse logistics, which have tackled the applicability of the waste, regardless of the publications of more normative countries such as Brazil. The latter, it seems, consist of excessive legislation on solid waste, urged on by uncommitted managers representing many different standpoints.

\section{Innovation Management Concepts}

Tidd \& Bessant (2015) state that innovation is the process of turning a good idea into a lucrative business; Tigre (2014) clarifies that innovation integrates different sectors, bringing together regions and members of the same institution to enjoy the strategic benefits of productive practices. It may be summed up by saying that technology management directs and coordinates organizations in their strategies to comply with sectors of the enterprise. Its actions are essential for the optimum use of equity and financial and human resources.

According to Starec (2012), innovation is a business strategy. It should be incorporated anywhere in a firm that involves people. In an increasingly competitive market, these actions add in different ways to the business capital. For this reason the concepts inherent in innovation technology should make intervention studies fundamental to the required change in complex social systems based on entrepreneurship.

Mattos \& Guimarães (2012) define technology as scientific, empirical or intuitive knowledge, developed jointly. Human beings depend on technology to meet the demands made in global emergencies. The changes required to serve the mainly strategic interests of markets can at times exert particular pressure. This constitutes the conceptual profile for the management of technological innovation that unifies contemporary research tasks in the problematic context of technologies for waste management.

Burgelman (2012) addresses the area of technology and innovation management as a new issue at the tip of biotechnology, predicting the possibility of innovation for three kinds of conceptual change: they will perhaps be incremental, such as the generation of cell phones and other mobile communicators; radical, such as those involving advanced digital communications; or architectural, such as reducing the size of physical components while increasing their capacity.

Appelt et al. (2014) discuss the global scenario involving the disposal of electronic solid waste. Their research work was approved by a scientific committee, and reported in the Minutes of the Thirtieth International Conference on Solid Waste Technology and Management in Philadelphia, USA; as the authors make clear, technological innovation tends to move forward systemically and without limits, causing irreparable damage to the environment from the irresponsible disposal of waste.

\section{Managing Sustainability}

In the view of Gomes (2014), sustainability can be seen as a set of strategic actions seeking solutions to problems relating to the environment. World Conferences on the environment, such as Rio 92 and Rio + 20, particularly emphasise urban centers. They cannot do otherwise, because the multiple threats from cities to the environment must generate opportunities, including those involving selective garbage collection. This invites citizens to share the reciprocal benefits of protecting the environment according to their per capita income. Gassenfurth et al. (2015) state that the preservation of forests, pollution of rivers, and biodiversity are all directly associated with environmental responsibility, but the authors warn that care must also be taken to safeguard urban conditions, since the management of sustainability in towns has received little consideration, though it should raise the same environmental concerns.

Dias (2014) discusses the green economy, with a new vision of ways to use natural resources efficiently while fostering sustainable economic growth. The mere presence of an individual in the environment is enough to result in degradation: this fact recalls to us that subsistence involves the exploitation of nature. It is from nature that man extracts the resources for existence, but for a green economy he should also be committed to considering the impact he makes and the benefits he might bring to balance it. 


\section{METHODOLOGY OF PREPARING}

Scientific method is understood to mean a set of core standards applied in a data search, aiming to get results close to a degree of certainty. The present study takes a qualitative and descriptive approach to nature which resembles the scientific method. It uses a case study to organize the data and environmental information which are addressed in the course of the research.

The procedures adopted here are common to case studies; in the literature, they are conducted by visiting an organization and cooperating with its workers (in this case, the ragpickers) in order to interpret its situation, as found in its strengths, weaknesses, opportunities and consistent threats. An analytical technique was considered for assessing the behavior of individuals and groups and its internal and external conflicts were thoroughly surveyed. Notes were taken, as Lacerda advises (2012), to ensure that the context was fully reported and the research is validated by the data collected and the problem areas tackled. A report was prepared, following the required research procedures, to describe the objectives to be pursued, always in accordance with the recommendations made by the authors.

\section{THE TECHNOLOGICAL MANAGEMENT OF WASTE COLLECTION IN THE WESTERN AMAZON SUB REGION}

The complex management of the technology for collecting solid waste in the Western Amazon sub Region raises many issues, the main ones for the present research being those which are contained in the conceptual theoretical framework of the topic itself. The proper disposal of solid waste is a recurrent problem in most municipalities in the State of Rondônia. As can be seen in the material published on the Internet, an unusual effort has been put into setting up a customized management system. It cannot be denied that the process is subject to entrepreneurship in the business of recycling, but its effects do not outweigh the needs of the region. Professional enablers proffer advice and make promises with regard to the characteristics of large metropolitan areas; they understand the possibilities of managing waste in the largest river basin in the world, since their clientele is cosmopolitan.

It should be kept in mind that it is impossible to manage the disposal of solid waste without jointly tackling environmental management, which requires skill and technical mastery in the preparation of reports, GIS, environmental records, waste management planning, licensing, inventories, audits, water management, reporting, and above all environmental education. It is worth noting that efficient strategies can only be created when management has an adequate profile; only those who know the region in depth can be said to have it.

\section{Interpretation of the form of concentration of solid waste in the group studied}

The documentation from the United Nations Conference on the Environment and Development (UNCED), held in Rio de Janeiro in 1992, reveals the need to provide the basic prerequisites of survival, such as adequate food, decent housing, employment, health and education, especially to people in extreme poverty (Dias 2014). Brazil recognizes that the municipalities running these programs in part or in whole in the State of Rondônia are currently in a minority and that rag-

TABLE 1

Definition of terms in the above diagram (concentration of solid waste)

\section{Element}

1. Contingency theory

2. Solid waste

3. Selective collection

4. Reverse logistic

5. Technological innovation management

6. Sustainability management

7. Public policy

8. Socio-economic environmental and institutional principles
Definition

This theory addresses the impact and influence of technology together with the environment, on bringing up issues in the study of solid residues

The slurry of the residue contaminates the water table as the result of the operation; gases are also significant pollutants

Urban dumps cause bad smells, vectors, insects, bacteria

Cooperating to enter the field of perception among the scavengers to constitute an organizational network

The complex technological management of solid waste collection in the western Amazon, considered from several standpoints

This element reveals the fragile social framework which obtains in the Amazonian region

Organized civil society for protecting the environment through reverse logistics and strong strategic action

Strong values of sustainability, economic viability, social justice and environmental soundness

Source: Authors (2016) 
pickers generally work in unsanitary and degrading conditions, in open dumps, exposed to diseases of all sorts and subject to accidents, mostly without any form of protection.

One of the risks to the Amazonian environment is the unsuitability of transport for carrying waste away from the disposal sites; the slurry of garbage contaminates the water table, while the gases emitted by it are significant pollutants, to say nothing of the bacteria and diseases carried by the vectors of this inadequate management operation. Therefore, it may

\section{Analysis of the positive impact of the disposal of solid waste in the Amazon region}

Under a SWOT analysis, the internal strengths of the region seem to be green manure production, tillage, soil conservation, preservation areas, eliminating pollution from the atmosphere.

Thus, it is a strong strategic action to employ advanced technology in a system used by citizens as a tool to strengthen consumer collaboration; it can organize civil society in support of environmental protection through reverse logistics. According to Mattos and Guimarães (2012), using the appropriate technology in a system gives a company sustainable advantage, stimulating the way in which it makes strategy making and thus securing its competitive advantage. It may be useful to consider the information contained in Table 2 below as a proposal.

Table 3 shows the results of this research which are organized according to the SWOT model. The elements are located as part of the internal or external conditions, whose implications should be taken as criticism from those interested in this approach.

\section{Intervention proposal for multiple benefits to the waste collection management process in the Amazon region}

The study calls for a valid proposal for intervention in its fragile scenario. The present situation involves individuals in the Amazon basin and, so long as the region's strong and weak points remain as previously interpreted and the current opportunities and threats continue to affect the area, it would consist of training and qualifying some of the residents. In such a scenario, the residents would be committed and motivated, to their great advantage, to practices which are aligned to sustainability.

The National System Collection Selective Awarded ERecycling - SINCOSPER - supported by institutional pillars, works for economic, social and environmental sustainability; it originated the view that sustainable advancement is the practical result of environmental education and its mission is to enhance the personalized relationship between industry and the distributors to consumers.

Economic viability for the users of a system of waste disposal (known as ecological holders of shares in Reverse Vending Machine Intelligent E-Recicla) is via an investment that offers immediate benefits from acquiring products and services from an ecological network. Meanwhile social viability search leveling would consider the social dignity of the collectors and remove them from their sometimes unhealthy current workplaces, such as landfills and dumps, training and then directing them to the social environment of public access areas for the concentrated collection of solid waste materials. In this activity, a sustainable environment would be aided by an environmental database. In addition, the sources of global warming would be reduced and people and institutions would be inspired, motivated and educated to consistently dispose of recyclable waste through the award of ecological collection points. Despite Tachizawa's warning (2011) that reckless human actions permanently change the ecological system, uncontrollable consumerism in contempt of the laws designed for environmental protection, has been a key factor in the increase of solid waste worldwide. Consumers mindful of consequences will be focusing on price, product quality and the social responsibility of manufacturing companies which have the same concerns. Through the combination of technologies and disciplines applied in the energy renewal cycle by the selective collection and recycling of waste, SINCOSPER provides economic sustainability. It promotes environmental conservation through sustainable marketing by

TABLE 2

Description of the problems identified

Problems

1. Current problems in the selective collecting chain

2. Waste destination

3. Environmental education
Descriptive of the situation problem

The concentration of waste in landfills and dumps; unhealthy manual sorting of collected waste; excessive accumulation of waste in urban dumps causing foul odors, vectors, insects, including flies, and clogged culverts.

Association of rewards with incentives for the proper disposal of waste, promoting economic inclusion coupled with the social demand for sustainable consumption, renewable energy and skills.

Integrating industrial business strategies, modes of distribution with commerce, on the part of public and private companies to promote environmental education and give social inclusion to rag-pickers and collectors

Source: Authors (2016) 
TABLE 3

SWOT analysis applied to solid waste management

1. Motivation to cooperate;

2. Possibility of action in a solidarity network;

3. Augmenting the family income;

4. Added quality in the life of societies;

5. Collective participation for sustainability.

\section{Strengths}

1. Resource capacity;

2. Social inclusion to improve the quality of life;

3. Change in the concept from examples;

4. Generation of new enterprises whose primary material is waste;

5. Generating wealth through reverse logistics opportunities

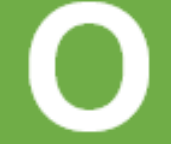

Opportunity
1. Lack of selective collection;

2. Volume of waste;

3. Logistics;

4. Vulnerability of those involved;

5. Lack of environmental education.

Weaknesses

1. Ineffectiveness of the government;

2. The existence of addiction due to corruption;

3. Inveterate consumerism;

4. Environmental, economic and social degradation;

5. Lack of environmental responsibility on the part of the waste generators.

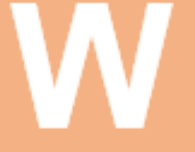

Source: Authors (2016).

generating ecological credits (greenback) as illustrated in Figure 1. Table 4 shows the operational flow of the reverse intelligent machine sales which are organized according to Figure 2, showing how the system works.

\section{CONCLUSION}

This study addressed the following question: What technology management model would be adequate for the selective collection of solid waste in the Amazon region? The

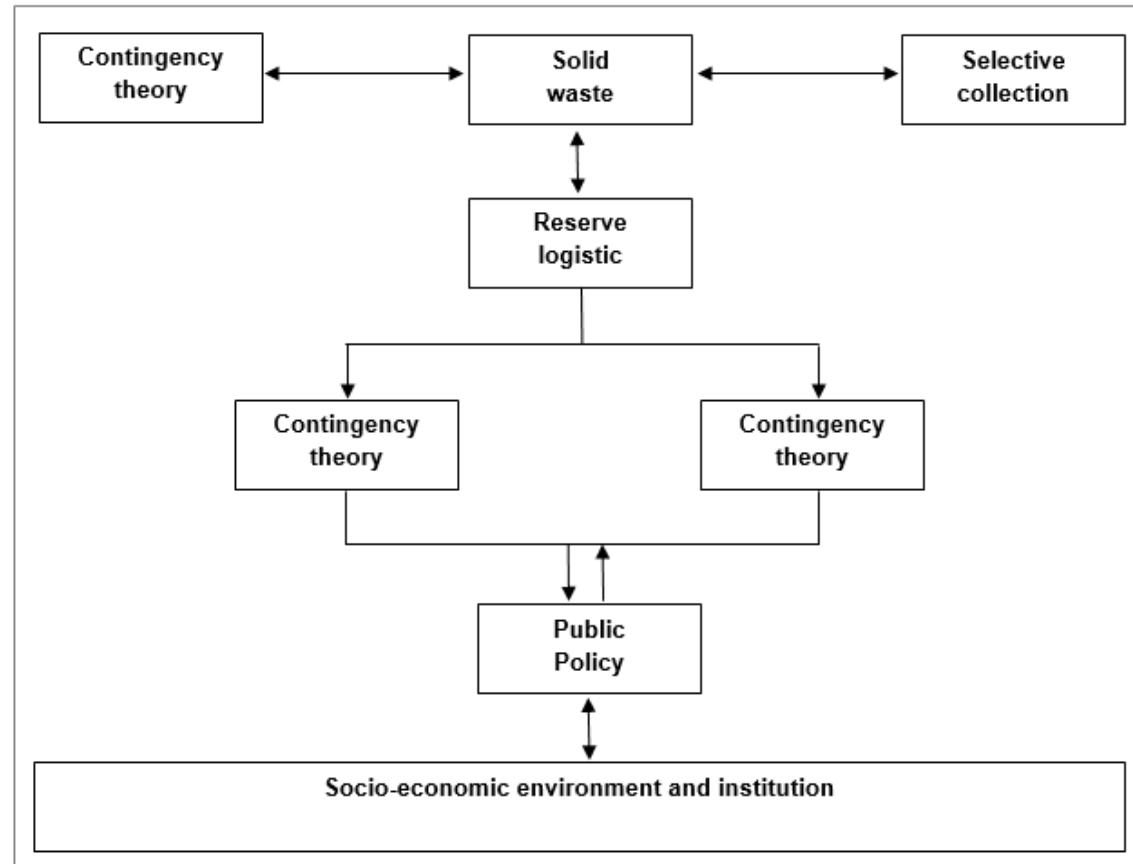

Source: Adapted from Burgelman (2012)

FIGURE 1

Concentration of solid waste 
TABLE 4

Operational Flow

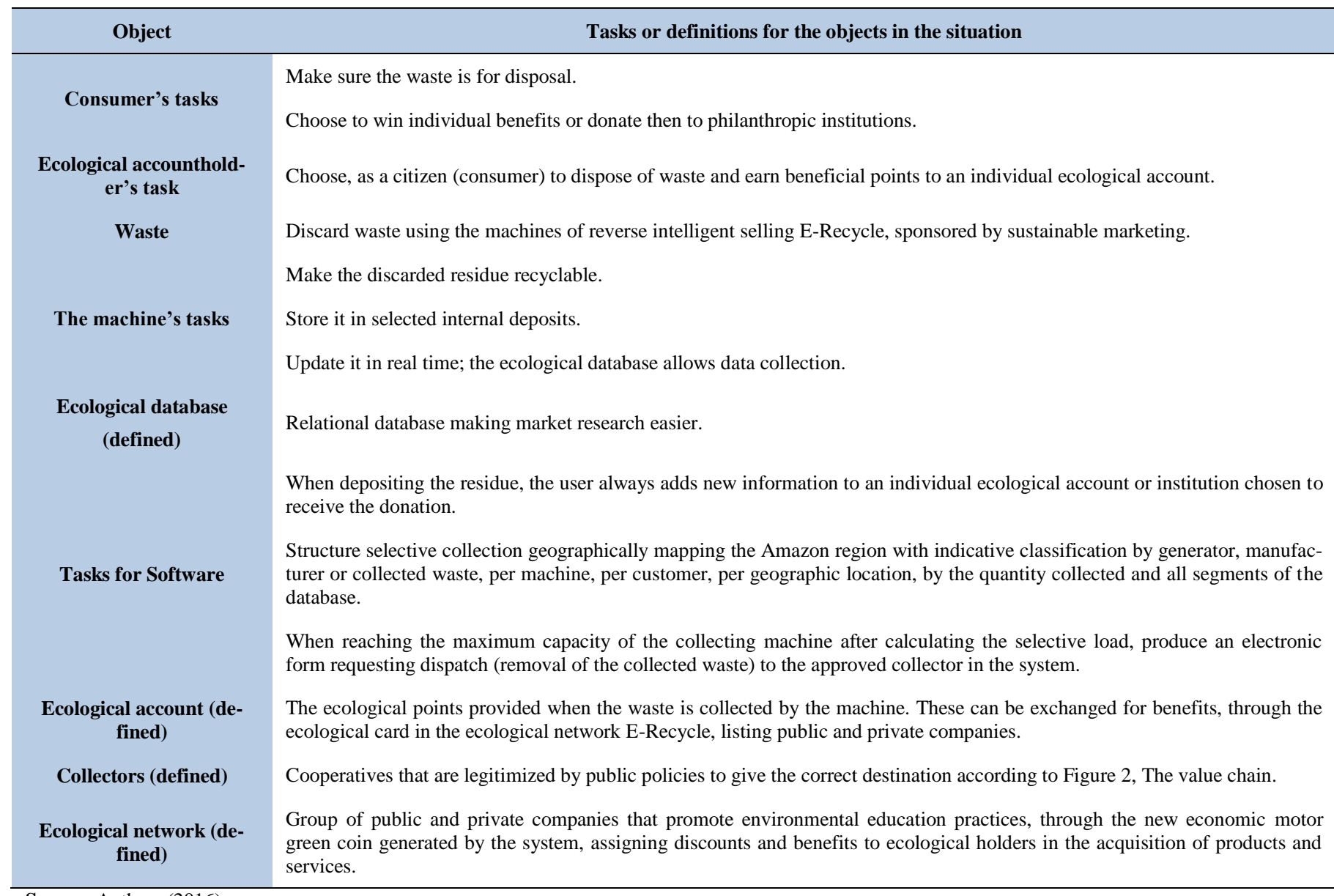

Source: Authors (2016).

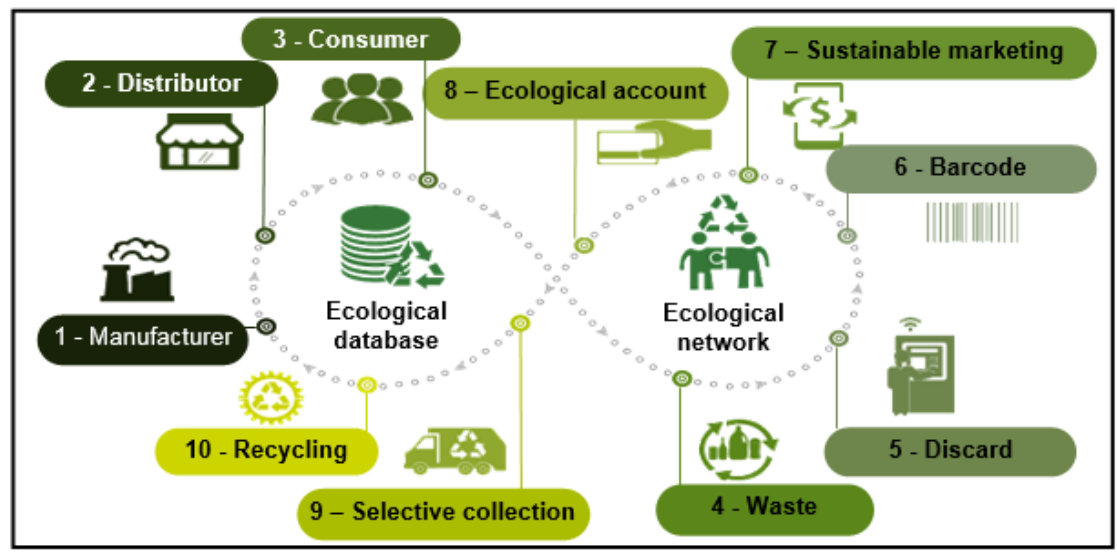

Source: Lucrative E-Recycle recycling

FIGURE 2

Value Chain

present paper answered the question by suggesting possible ways of bringing about the complex technological management of solid waste in this region. From the beginning, by organizing cooperative associations and networking, it fo- cused on the task of reverse logistics and cooperation to enter the field of perception of scavengers who form themselves into organizational networks based on contingency theory.

To begin with, this paper interpreted the way in which 
solid waste was concentrated in this area. It went on to suggest a contingency look at intervention that might create multiple benefits from managing waste collection, noting the positive impact generated by minimizing the volume of solid waste in the Amazon basin.

The practical exercise of the quadrants (strengths, weaknesses, opportunities and threats) collectively known as SWOT highlighted the positive environmental impacts of an initiative to concentrate the disposal of solid waste in the Amazon; for example, green manure, tillage, soil conservation, preservation areas, suppression of air pollution as well as the reduction of negative events such as fires, deforestation and contaminated soil. This initiative formed a strategy that lets researchers transform informational data gathered over time, allowing facts to be interpreted and reported as intended. Thus, a system can be presented involving smart selective collection machines carrying the enterprise symbol, based on technology management in the above task and it is suggested that the system could encourage cooperation to support the progress of the skills essential to the development of proper ways of managing solid waste.

In this sense, this study admits that cognition does not offer any degree of environmental certainty, but it confirms the value of technology management for the collection of waste in an organized, dynamic and sustainable way. Reverse logistics are addressed as a solution, with a primary chain of sustainability values, economic viability, social justice and environmental soundness. The elimination of a significant amount of solid waste in this region echoes the positive impacts of such an intervention anywhere and at any time.

\section{ACKNOWLEDGMENTS}

We thank the University of Beira Interior, Faculty of Social and Human Sciences, Department of Management and Economics, Post-Doctoral Programme in Management and Economics, with a focus on Management Strategy for Innovation and Sustainability, Covilha, Portugal. Site: http: //www.ubi.pt/Entidade/Ciencias_Sociais_e_Humanas

\section{REFERENCES}

Appelt, Irene Anelize et al. (2014). Electronic waste management and the discarding of technology. Proceedings of the thirtieth international conference on solid waste technology and management. Philadelphia: ICSW.

BRAZIL, Presidency of the Republic. (2010). Law No. 12,305 , providing for the National Plan of Solid Waste of 02 August 2016.

BRAZIL, Ministry of the Environment. (2016).

BRASIL, Ministério do Meio Ambiente. Resíduos Sólidos. Disponível em: <http://www.mma.gov.br/cidades-sustent aveis/residuos-perigosos/logistica-reversa > Access on 16 August.

Burgelman, Robert A., Christensen, Clayton M., Wheelwright, Steven C. (2016). Strategic Management of Tech- nology and Innovation: Concepts and Solutions. Porto Alegre: AMGH 2012.

D'Ambros, Jorge; Gonçalez, Joaquim Carlos; ANGELO, Humberto. (2016). Contributions to the deployment of furniture center in Tocantins Central Region. Available in <http://www.scielo.br/scielo.php?script=sci_arttext\&pid= S010477602012000300004\&lng=pt\&nrm=iso>. access on 15 August.

Demajorovic, Jacques et al. (2016). Integrating companies and recycling cooperatives in reverse flows of postconsumer waste: Underdog case. Available in <http://www.scielo.br/scielo.php?script=sci_arttext\&pid=

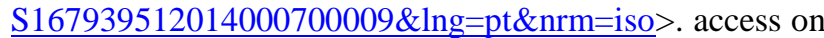
15 August.

Denhardt, Robert B. (2015). Theories of Public Administration. São Paulo: Cengage Learning, p. 167.

Dias, Reinaldo. (2014). Eco-innovation: the way for sustainable growth. São Paulo: Atlas.

Gassenfurth, Walter et al. (2015). Business Management and Sustainability. Rio de Janeiro: Brasport, p. 236-237.

Gomes, Marcos Antonio Silvestre. (2016). Parks urban, public policy and sustainability. Mercator (Fortaleza). Fortaleza, v. 13, no. 2, p. 79-90, aug. 2014. Available in <http://www.scielo.br/scielo.php?script=sci_arttext\&pid= S1984-22012014000200079\&lng=pt\&nrm=iso>. hits in 20 August.

Lacerda, RogérioTadeu de Oliveira; Ensslin, Leonardo; Ensslin, Sandra Rolim. (2016). A bibliometric analysis of the literature on strategy and performance evaluation. <http://www.scielo.br/scielo.php?script=sci_arttext\&pid= $\underline{\text { S0104530X2012000100005\&lng=en\&nrm=iso > Access }}$ on August 16.

Mattos, João Roberto Loureiro \& Guimaraes, Leonam dos Santos. (2012). Management of Technology and Innovation: A Practical Approach. São Paulo: Saraiva, p. 111.

Nobre, Farley Simon; Tobias, Andrew M; Walker, David S. A view of the skills-based company: strategic and contingency contexts. Available on <http://www.scielo.br/ scielo.php?script $=$ sci_arttext $\&$ pid $=S 1415655520110003000$ 04\&lng=pt\&nrm=iso $>$. accessed on 14 August.

PARANÁ. (2016). Department of the Environment. http://www.meioambiente.pr.gov.br/arquivos/File/coea/pn cpr/O que sao PoliticasPublicas.pdf. Accessed on $\mathrm{Au}-$ gust 17.

Philippi, Arlindo, Jr.; Sampaio, Carlos Alberto Cioce; Fernandes, Valdir. (2012). Management of Public Nature and Sustainability. Barueri: Manole (Environmental Collection).

Starec, Claudio. (2012). Information Management, Innovation and Competitive Intelligence: Transforming Information into Competitive Advantage in Organizations. São Paulo: Saraiva.

Tachizawa, Takeshy. (2011). Environmental Management and Corporate Social Responsibility: Focused Business Strategies in the Brazilian reality. São Paulo: Atlas.

Tigre, Paulo Bastos. (2014) Innovation Management: Saving Technology in Brazil. Rio de Janeiro: Elsevier. 
